\title{
EXPERIMENTAL AMITOSIS IN ONION ROOT TIP
}

\section{H. E. JORDAN}

\section{INTRODUCTION}

My recent study of amitosis in the lining epithelium of the epididymis of the mouse, ${ }^{1}$ and in certain other ciliated epithelia, led me to the tentative conclusion that the fundamental causative factor here involved is the partition and consequent destruction of the centrosome in the formation of "basal granules" from which the cilia grow. The suggestion was made that direct cell division is proximally related to factors inducing loss of integrity or impairment of function of the centrosome. Such factors are various, including those originally and recently sugested, namely, intense secretory activity, and disturbed metabolic conditions characterized as "degenerative" (Flemming, ${ }^{2}$ Ziegler, ${ }^{3}$ vom Rath, ${ }^{4}$ et cetera), lack of adequate nutriment (Child, ${ }^{5}$ Patterson ${ }^{6}$ ), insufficient supply of oxygen (Wieman ${ }^{7}$ ).

To test experimentally this hypothesis a series of experiments were made by growing onion roots in water to which ether was added. Two assumptions, apparently legitimate, are involved: I) the onion cell has an analogue (indiscernible) of the centrosome of animal cells, similarly concerned in the formation of the mitotic spindle ; 2) ether, and other anæsthetics, may be expected to produce a "stupefying" effect upon the "dynamic center" of the cell thus enforcing a direct method of actual multiplication.

The sole result claimed for the investigation is the fact that onion roots continue to grow vigorously in water to which small quantities of ether are added, and that many of the cells are in various phases of undoubted direct division. No originality is claimed either for the hypothesis or for the experimental procedure. I believe, however, that the facts adduced from the study of the epididymis of the mouse offer the strongest histologic evidence yet reported in support of the hypothesis. The experiments were under- 
taken simply to test this hypothesis. The same idea must have suggested the experiments of Pfeffer and Nathansohm ${ }^{8}$ with spirogyra grown in water with ether, and of Wasielewski ${ }^{\bullet}$ with Vicia faba roots grown in chloral hydrate solution.

Nathansohm ( 1900 ) claims to have induced amitosis in spirogyra and the desmid closterium by transferring karyokinetically dividing filaments to a $\mathrm{I} \%$ solution of ether in water. Roots of Phaseolus, Lupinus, Phalaria and Marsilia were similarly treated, but without success in changing cell-division from the indirect to the direct method. Treatment of growing roots of Vicia faba with a $0.7 \%$ chloral hydrate solution for various periods is claimed by Wasielewski (I902-I904) to change the majority of cell divisions from mitotic to amitotic. Nemec ${ }^{10}$ (I904), however, interprets the cell pictures (in roots of Vicia faba, Allium cepa and Pisum sativum, treated with $0.75 \%$ chloral hydrate solution) in terms of nuclear fusions, and disputes their amitotic significance. My experiments with onion root tip grown in ether solution, on the contrary, show unmistakable amitosis. However, in view of the fact that the roots grew vigorously, and that mitoses are always exceedingly rare, and in several instances totally lacking, indisputable healthy amitotic divisions (i. e., apparenty non-degenerative) are unexpectedly relatively rare.

\section{Description OF THE EXPERIMENTS}

The procedure was simply to place an onion, with stem and roots either absent or just appearing, into the mouth of a small jar so selected for size that the root pole of the bulb was immersed in the solution to a depth of about half an inch. The experiments with controls consisted of three series, with summarized results as follows:

\section{First Series}

a) Bulb in $4 \%$ alcohol solution.-Neither stem nor roots appeared.

b) Bulb in water unchanged for four days.-Both stem and roots appeared. Of 5 roots examined, two were disintegrating; the remainder showed occasional mitoses in the plerome cells and several doubtful instances of degenerative amitoses in the pleriblem cells. 
c) Bulb in water to which a few drops of ether were added thrice daily for two days.-Stem barely developed, many vigorously growing roots appeared. Of 6 roots examined only two showed mitotic figures, limited to the plerome; and all showed occasional direct divisions among the periblem cells.

\section{Second Series (three to eight tips each)}

a) Bulb with roots just showing; in water from Io o'clock $\mathrm{A}$. M. to 4.30 P. M.-Normal; many mitoses both in plerome and periblem; also a few in dermatogen.

b) Bulb in water, unchanged for 4 days.-Mitoses still frequent; a few tips distintegrating.

c) Bulb in water changed twice daily for 4 days.-Normal; numerous mitoses.

d) Bulb in moist cotton I day.-Tips of young development; neither mitoses nor amitoses.

e) Bulb in moist cotton 2 days.-Distintegrated.

f) Bulb in water unchanged for one week.-Normal; many mitotic figures.

g) Bulb in water + ether, changed twice daily for I day.-Neither mitoses nor amitoses.

h) Bulb in water + ether, changed twice daily for 3 days.-No mitoses; many amitoses.

i) Bulb grown in cotton moistened with water and ether for 4 days.-No growth of either stem or roots.

\section{Third Experiment}

a) Bulb in water to which a small amount of ether was added three times daily for 5 days, and allowed to remain in the unchanged water for 2 days longer.-Normal; numerous mitotic figures.

The roots were fixed in Flemming's strong solution.

The sections were cut at from 5 to ro microns, and stained in iron hæmatoxylin, with and without eosin counterstain.

\section{Description of Normal Root}

A brief description of normal conditions seems desirable before proceeding to an analysis of the experimental results of the several 
series. The description is based upon an excellent preparation previously made and used for demonstrating mitotic figures in classroom work.

The root-tip contains characteristic cells in the several regions: dermatogen, periblem, plerome, and root-cap. The dermatogen consists of from 2 to 5 layers of very long rectangular cells, with the longest axis parallel to the long axis of the root. The nucleus is pale and finely granular, with one or several nucleoli. The cytoplasm contains large vacuoles and numerous deep-staining spherical granules of various sizes (mitochondria). Some of the cells are in process of indirect division.

The periblem consists of from 7 to Io rows of small rectangular cells surrounding the central plerome. The longest axis of these cells is generally perpendicular to that of the dermatogen cells. The nuclei are pale staining, finely granular or delicately reticular, mostly with two nucleoli frequently surrounded by a clear halo. The cytoplasm is considerably vacuolated and contains granules similar to those described for the dermatogen. The cells of the layers, more particularly from the third inward and from just above the upper

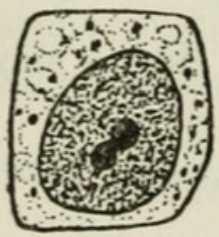

1

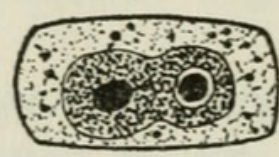

2
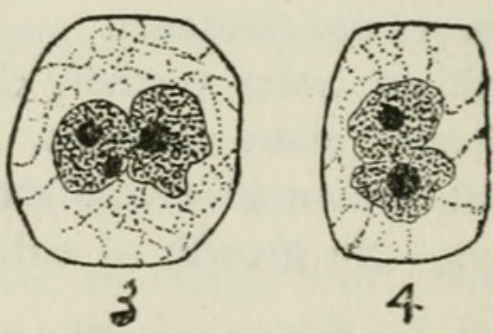

Fig. I. Sketch of periblem cell from normal root showing early process in constriction of nucleolus. Abundant earlier and later phases also appear. The vacuolated cytoplasm contains deeply staining granules (mitochondria). The nucleus is pale-staining, finely granular, or delicately reticular.

Fig. 2. Typical rectangular bi-nucleolate cell of periblem of normal root. One of the nucleoli is surrounded by a clear halo, probably a fixation artefact.

Figs. 3 and 4. Periblem cells from root undergoing early degenerative changes. The cytoplasm contains huge vacuoles, and lacks mitochondria. The nuclear wall is irregular and apparently suffering an equatorial constriction closely simulating, if not actually, a direct division. Excessive number of nucleoli, i. e., more than two is a common condition in the cells of these tips. 
limit of the root-cap, show large numbers of nucleoli at all phases of constriction and separation in the process of the formation of binucleolate nuclei (Figs. I and 2). The appearance is exactly that of Remak's classic illustration of the initial step in amitosis. However, the further steps, viz., nuclear and cytoplasmic fission, nowhere appear; and mitoses at all phases are very abundant.

The plerome consists of a variable number of layers. The cells are long rectangular, relatively huge rectangular, and approximately square, in shape. The nuclei are large oval or spherical, mostly with deep-staining coarse reticulum, and with one or two chromatic nucleoli, sometimes appearing achromatic. The cytoplasm contains smaller vacuoles than in the periblem and dermatogen cells and relatively fewer mitochondria. Mitoses are most abundant in this portion. Two chromatic nucleoli are frequently present even at the segmenting spireme stage, of irregular oval shape but with sharp contour.

The root-cap contains larger and smaller polyhedral cells with enormous vacuoles in the cytoplasm and very sparse mitochondria, and pale granular nuclei with one or generaly two nucleoli. These cells are only rarely seen in mitosis in this preparation.

The points of special significance in normal root tip for this study are: I) absence of amitoses; 2) great abundance of mitoses, especialy in plerome; 3) nucleolar constriction in, and binucleolate character of, the periblem cells ; 4) presence of mitochondrial granules (an index of virility); and 5) general pale-staining, finely granular, character of the periblem nuclei.

\section{Analysis of the First Series of Experiments}

The non-appearance of roots or stem on the bulb in the $4 \%$ solution of alcohol is interpreted to mean that this solution was too strong to permit development. Since the experiment was not repeated with weaker solutions the interpretation must be tentative; but since this is the only complete failure of development in the several series (save one with bulb in cotton moistened with ether solution) it is very plausible. The reason for not further experimenting with alcoholic solutions at this time was the fact that positive results were obtained with the ether solutions. 
The roots of the bulb grown in water unchanged for four days differed somewhat from normal, and several were in the later stages of disintegration. Mitoses are numerous in the plerome cells, but practically absent in the periblem cells. Mitochondrial granules are relatively sparse and pale-staining. Relatively more cells have two nucleoli; a number have three (Fig. 3) and even four nucleoli. The periblem nuclei are frequently irregular in outline, with numerous blunt processes; a few may possibly be in process of amitosis (Figs. 3 and 4). On this bulb the stem grew very vigorously. Cytologic appearances must probably be interpreted in terms of early degeneration, involving possibly slight amitotic division.

Roots of bulbs grown in a $3 \%$ aqueous solution of ether grew very vigorously, while the stem developed but little. This result seemed to indicate a stimulating effect to root formation. causing indirectly a retardation of stem growth. The jar with bulb was covered under a larger jar to prevent excessive volatilization of the ether. When uncovered as in the later experiments this differential growth of roots and stem was not so evident. The roots have a perfectly healthy appearance, in section in all respects like the normal except that mitoses are almost, and in some tips entrely, lacking even in the plerome cells. Amitoses are abundant in the periblem cells (Figs. 5 and 6), usually appearing in groups of four or eight. Many of these nuclei have an irregular contour with short pseudopodial processes like in the foregoing set of roots. Only rarely can the final process of the formation of a wall between the
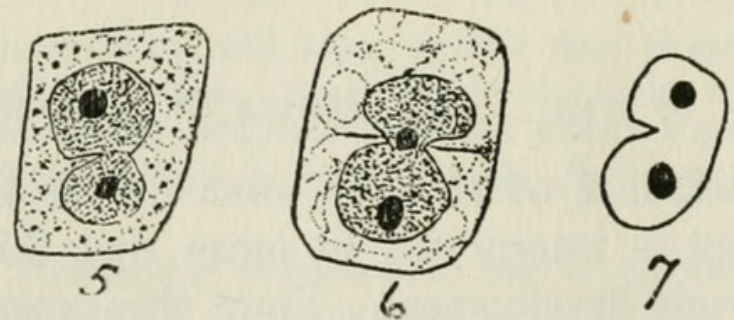

Fig. 5. Periblem cell from root grown in $3 \%$ ether solution (first set of experiments), showing early stage in amitotic division.

Fig. 6. Similar cell, showing a later phase of direct division, including the formation of a new cell membrane between the separating daughter nuclei. The cytoplasm contains large vacuoles and lacks mitochondria, in which respects it resembles a degenerating cell.

Fig. 7. Diagram of frequent type of nucleus showing character of initial phase of nuclear direct division. 
amitotic moieties be seen (Fig. 6). Many nuclei show a sharp cut at one point on the surface (diagram, Fig. 7), the initial step in the nuclear constriction. This appearance is practically lacking in the previous set.

The number of bi-nucleolate cells does not seem relatively larger than in the normal or degenerating tips. However, multinucleolate cells are absent. No significance can be attached to the bi-nucleolate nuclei, from the standpoint of amitosis, since these are almost equaly abundantly present both in normal and degenerating tips. Still, when followed by nuclear fission, as occasionally in tips grown in ether solution, the nucleolar fission represents the initial step in amitosis.

There remains no question, I believe, that true amitosis occurs in these tips, and as the result of ether in the water; but whether this result is direct (i. e., specific, the ether acting anæsthetically upon the astral system) or indirect (i. e., due to abnormal environmental conditions produced by the ether), must remain uncertain. However, the fact that undoubted amitoses are relatively much more abundant in the tips grown in water with ether than the doubtful ones in the unchanged water speaks in favor of a direct retarding influence to centrosomal activity. This conclusion is further strengthened by the fact that the roots grew vigorously; and that no cytologic indications of degeneration, beyond a number of irregular nuclei, appear. The result is disappointing, however, in that the amitoses are unexpectedly rare in view of the rapid growth and the absence of mitoses. It cannot be asserted with full surety that growth was entirely by amitosis, since a few mitoses appear in the plerome cells; and, moreover, the possibility remains that the tips were cut at the interval between mitotic waves. But if this were the true explanation of the absence of mitoses, not all of the roots would be expected to show substantially the same condition. It seems then that amitosis plays a considerable part in the growth of root tips in water with ether, and that it does not necessarily signify degeneration since the tips after two days are still vigorous and normal. That the complete amitotic process is consummated, though the final step is difficult to demonstrate, is further indicated by the complete absence of bi-nucleolate cells. 
It seemed possible that the degeneration and incidental probable amitosis of the roots grown in unchanged water might be due to the presence of the extract of onion held by the water; also, this method of sprouting bulbs is so far from normal that only degeneration phenomena (including amitosis) could perhaps be expected. To check these uncertainties, and to further test the influence of ether on mitotic proliferation, the second set of experiments was devised.

\section{Second Series of Experiments}

Growth in moist cotton gave wholly negative results as the above summary shows. This evidently makes a most unfavorable growth medium.

The roots grown in water changed twice daily were normal.

Those grown in unchanged water, even after an entire week, were still vigorous and essentially normal. Thus extract of onion appears to have no inhibitory or deleterious effect, at any rate if allowed to volatilize freely. In the previous experiment the bulb fitted more closely into the mouth of the jar. The cause of the degeneration in several roots in the first series of experiments remains obscure.

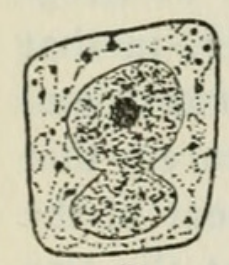

8
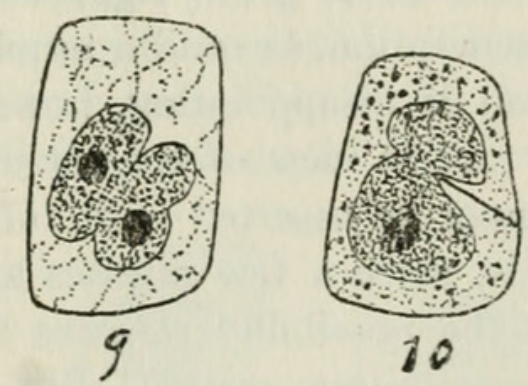

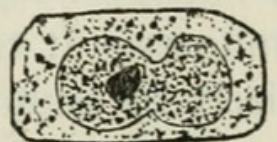

11

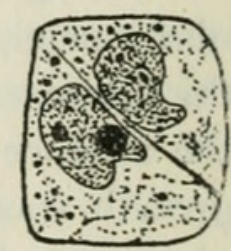

12

Figs. 8, 9 and ro. Periblem cells from roots grown in ether solution (second set of experiments), showing three stages in the nuclear constriction; in Fig. ro a new cell membrane is forming and has progressed into the depth of the constriction on the right.

Figs. II and I2. Periblem cells from the same set showing initial and final stages in direct division.

The bulb grown in the ether solution again sprouted roots, showing the identical condition described in the first series (Figs. 8 to 12$)$. 


\section{THIRD EXPERIMENT}

The third experiment was planned for the purpose of testing whether tips induced to presumable amitotic growth by ether could again revert to mitotic growth on resumption of normal conditions. With this end in view a bulb was placed as above in a $3 \%$ solution of ether (ether being added thrice daily) for 5 days, and then allowed to continue development for two more days without further addition of ether. Six roots were cut and fixed at the end of the seventh day. All except two which were distintegrating were apparently normal and the majority contained abundant though frequently atypical mitotic figures. The result of this experiment indicates that the direct cell division in the roots developing in the ether solution does not necessarily lead to degeneration. Significantly, too, several of the roots showed a few bi-nucleate cells; as if the amitotic process had been halted short of consummation at the disappearance of the ether from the water.

\section{Conclusion}

Onion root-tips grown in appropriate solutions of ether (approximately $3 \%$ in water) show an almost complete absence of mitotic figures, and a considerable number of periblem nuclei in process of direct division. Amitosis is not present in roots grown in pure water, while mitoses are abundant. Ether would appear to have a "stupefying" effect upon the astral apparatus, preventing karyokinetic cell division. Certain appearances (e. g., pale periblem nuclei of irregular contour) suggest degeneration; but roots similarly treated with ether for several days and then allowed to develop for several more without further addition of ether, proceed to grow normally and show abundant mitoses. Thus the amitosis seems capable of reversion to mitotic type. These results confirm those of Pfeffer and Nathansohm with spirogyra and closterium, and those of Wasielewski with roots of Vicia faba grown in chloral hydrate solution. Wasielewski, however, could only report a majority of direct, as compared with indirect, divisions in Vicia faba; and my own results are disappointing in that, in view of the almost total absence of mitoses, undoubted amitoses are rare. Concerning a certain small number, however, there can be no doubt. It must 
still remain uncertain whether these represent early indications of a reversible degenerative process due to unfavorable environment, or the result of a direct influence on the part of the ether upon the achromatic spindle complex. The apparent selective action upon the periblem cells also remains obscure. Whether degenerative in significance, as seems more probable in view of certain cytologic correspondences above detailed, or otherwise, the amitosis present in etherized roots seems clearly the result of a superior sensitiveness on the part of the centrosome and the astral associates to untoward environmental influence.

\section{LITERATURE}

i. JoRDAN, H. E.

Amitosis in the epididymis of the mouse. Anat. Anz., Bd. 44. 1913 .

2. Flem Ming W.

Neue Beiträge Zur Kentniss der Zelle. Archiv. mikr. Anat., Bd. 37. I891.

3. Ziegler, H. E.

Die biologische Bedeutung der amitotischen Kerntheilung in Tierreiche. Biol. Centrbl., Bd. II. I89r.

4. Vom Rath, O.

Ueber die Bedeutung der amitotischen Kernteilung im Hoden. Zool. Anz., Bd. 14. I89r.

5. Child, C. M.

Amitosis as a factor in normal and regulatory growth. Anat. Anz., Bd. 30. 1907.

6. Patterson, J. T.

Amitosis in the pigeon's egg. Anat. Anz., Bd. 32. Ig08.

7. Wieman, H. L.

A study in the germ cells of leptinotarsa signaticollis. Journ. Morph., vol. 2I, No. 2. 1910.

8. Nathansohn, A.

Physiologische Untersuchungen über amitotische Kernteilung. Jahr. Wiss. Bot., 35 :I. 1900.

9. Wasielewsisi, WaLdemar von.

Theoretische und experimentelle Beiträge Zur Kentniss der Amitose. Jahrb. Wiss. Bot. I Abschnitt, I902, Bd. 38: Heft. 3. II Abschnitt, I904, Bd. 39: Heft. 4.

I0. Němec, B.

Ueber die Einwirkung des Chloralhydrats auf die Kern-und-Zelltheilung. Jahr. Wiss. Bot. 39:4. 1904.

Anatomical Laboratory, University of Virginia. 


\section{$2 \mathrm{BHL}$ Biodiversity Heritage Library}

Jordan, H E. 1913. "Experimental Amitosis in Onion Root Tip." Transactions 32, 103-112.

View This Item Online: $h$ https://www.biodiversitylibrary.org/item/84910

Permalink: https://www.biodiversitylibrary.org/partpdf/90783

\section{Holding Institution}

University of Toronto - Gerstein Science Information Centre

\section{Sponsored by}

University of Toronto

\section{Copyright \& Reuse}

Copyright Status: Not provided. Contact Holding Institution to verify copyright status.

This document was created from content at the Biodiversity Heritage Library, the world's largest open access digital library for biodiversity literature and archives. Visit BHL at https://www.biodiversitylibrary.org. 